\title{
Kajian Estetika dan Unsur Pendukungnya pada Keraton Surakarta
}

\author{
Imam Santosa \\ KK Ilmu Desain dan Budaya Visual \\ Fakultas Senirupa dan Desain, Institut Teknologi Bandung
}

\begin{abstract}
Abstrak. In Javanese culture, the Keraton of Surakarta Hadiningrat (Surakarta Hadiningrat Palace) is classified as one of the highly valued Javanese historical objects. It is due to the fact that the history of the Palace's construction has a close connection with the history of the previous Javanese kingdoms, especially those belong to the Mataram Rajakula (dynasty) which was established in the year 1508 of Javanese calendar (Saka) or 1582 AD. The word "keraton" originates from the word 'ke-ratu-an, a manifestation of highly valued creation or 'Pamesu Budi' (in Javanese language) of a king, his men of letters, and his artists, the creation that caters the Javanese life values and norms. From its meaning, the design of the Surakarta palace-in Javanese language--characterizes the following: nyipati wewangun toto lahir, sinartan dhamang dumateng pagedhong pikajeng, manunggaling kang agal lan alus, whose translation says that the merger between physical and metaphysical thing, between logic and non-logic, between the soft and hard, and between wadaq and thought.
\end{abstract}

Keywords: aesthetics; representation; the truth (das Wahre); the good (das Gute); the beauty (das Schone).

\section{$1 \quad$ Pendahuluan}

Bangunan Keraton Surakarta Hadiningrat merupakan salah satu karya arsitektur peninggalan sejarah yang memiliki nilai tinggi, khususnya bagi kebudayaan Jawa. Sejarah berdirinya Keraton Surakarta sangat erat kaitannya dengan sejarah kerajaan-kerajaan sebelumnya, yakni kerajaan-kerajaan yang termasuk dalam Rajakula (dinasti) Mataram, yang didirikan oleh Panembahan Senopati atau Raden Sutawijaya pada tahun 1508 Jawa (1582 Masehi). Dalam catatan sejarah, Kerajaan Mataram mencapai puncak kejayaan pada masa pemerintahan Sultan Agung Hanyakrakusuma (cucu Panembahan Senopati) yang memerintah pada tahun 1538-1570 Jawa atau 1613-1645 Masehi.

Keraton Surakarta merupakan suatu bangunan monumental yang memiliki kesan sakral serta mencerminkan sifat-sifat yang agung dari kehidupan kerajaan. Sifat dari perwujudannya merupakan smbolisasi dari falsafah hidup serta alam pikiran yang mendasarinya. Bagi orang Jawa, Keraton Surakarta dipandang sebagai 'Pusering tanah Jawi' yang berarti sebagai titik pusat dan

Received December $12^{\text {th }}$ 2006, Revised February $10^{\text {th }}$ 2007, Accepted for publication March $1^{\text {st }} 2007$. 
sumber kebudayaan Jawa. ${ }^{1}$ Berdasarkan fakta historis, proses pembentukan discovery and invention pada kebudayaan Jawa berlangsung hampir tanpa konflik. Keunikan tersebut telah menjadi berbagai objek penelitian para ahli, baik dari dalam maupun luar negeri. ${ }^{2}$ Dalam pandangan Jawa, prinsip kerukunan bukan pada proses penciptaan keselarasan sosial, melainkan lebih kepada sikap untuk tidak mengganggu keselarasan yang sudah ada. Keselarasan sosial dianggap sebagai situasi normal yang ada dengan sendirinya selama tidak diganggu, karenanya prinsip kerukunan menuntut untuk mencegah segala pola laku yang dapat mengganggu keselarasan dan ketenangan dalam masyarakat yang disebut oleh Ann Wilner (1970:258) sebagai 'prinsip pencegahan konflik'. Keraton Surakarta tidak dapat dipisahkan dari kaidah rukun dan hormat. Pada kaidah rukun, keraton merupakan suatu susunan dari berbagai aturan dan norma yang terlembagakan. Sedangkan pada kaidah hormat, keraton merupakan bentuk pengidentifikasian diri terhadap norma dan tataatur dari seorang Raja. (Honigmann, J., 1959:11-12)

\section{$2 \quad$ Aspek Metodologi}

Penelitian estetika keraton terkait dengan artifak budaya keraton yang telah mencapai puncak proses pembentukannya kemudian disebut sebagai budaya klasik (suatu produk yang telah baku dan memiliki seperangkat makna dan prosedur dalam pembuatannya). Oleh karenanya 'frame' yang digunakan tidak semata-mata bentuk dan fungsi, tetapi hal-hal yang bersinggungan dengan nilai, makna dan arti, seperti tercermin dalam ungkapan Paku Buwono X sebagai berikut:

"Karaton Surakarta Hadiningrat, haywa kongsi dinulu wujude wewangunan kewala, nanging sira padha nyumurupana sarta

\footnotetext{
${ }^{1}$ Bagi rakyat Jawa, Keraton selain sebagai pusat politik dan budaya, juga merupakan pusat keramat kerajaan. Keraton adalah tempat raja bersemayam, dan raja merupakan sumber kekuatan kosmis. (baca: Heine Geldern, 1963:7) Paham tersebut sangat jelas dalam gelar penguasa keempat kerajaan di Jawa Tengah hasil perpecahan Mataram II. Kedua penguasa Yogyakarta menyebut diri Hamengku Buwana (yang memangku jagad raya) dan Paku Alam, para penguasa Surakarta bernama Paku Buwana (Paku jagad raya) dan Mangkunagara (yang memangku negara). Di zaman pra Islam, raja dipandang sebagai penjelmaan dewa. Biasanya Syiwa dianggap menjelma dalam diri raja, selain itu ada juga yang dianggap sebagai jelmaan Wisnu seperti Raja Kertarajasa pendiri kerajaan Majapahit yang diabadikan pada sebuah patung sebagai hari-hara, campuran antara Syiwa dan Wisnu. (baca: Magnes Suseno, 2001:107-110).

2 Greetz,H. (1961:146) menyatakan, bahwa terdapat dua kaidah yang menentukan dalam pola interaksi masyarakat Jawa. Kaidah pertama, bahwa pada setiap situasi, hendaknya manusia Jawa bersikap sedemikian rupa sehingga tidak menimbulkan konflik, yang disebut sebagai prinsip kerukunan. Kaidah kedua, menuntut agar cara berbicara dan membawa diri selalu menunjukan sikap hormat terhadap orang lain yang disebut sebagai prinsip hormat. Kedua prinsip tersebut menentukan bentuk konkret semua interaksi sosial pada masyarakat Jawa.
} 
hanindakna maknane kang sinandi, dimen dadya tuntunan laku wajibing urip hing dunya tumekeng delahan."

Artinya:

("Janganlah keraton Surakarta Hadiningrat hanya dilihat dari wujud/bentuk bangunan fisiknya saja, tetapi hendaknya diketahui, dimengerti serta dijalankan makna pesan-pesan yang tersirat dan tersurat, agar dapat menjadi tuntunan menjalankan kewajiban hidup di dunia dan akhirat”).

Mengingat hal yang demikian, maka untuk mengungkapkan permasalahan yang terkandung dalam estetika Keraton Surakarta, perlu pertimbangan metoda sebagai berikut:

1. Dalam kepustakaan Jawa, tidak ada satupun ditemukan mengenai ukuran yang pasti didalam menilai keindahan. ${ }^{[11]}$ Untuk itu perlu pengolahan dari berbagai sumber yang berbeda; seperti mencari berbagai kemungkinan untuk menghubungkan sumber pustaka Jawa, termasuk serat dan pantun; wawancara khusus dengan tokoh, ahli dan pakar yang dianggap menguasai budaya Jawa.

2. Terlebih dahulu harus dicari relasi antara budaya Jawa dengan keraton Surakarta sebagai suatu artifak dalam sistem kebudayaan Jawa, serta bagaimana kebudayaan Jawa berkembang dalam proses transformasi budaya.

3. Meneliti estetika keraton merupakan suatu kajian budaya, yang dituntun oleh pemikiran teoritis, tinjauan estetika serta metoda historis baik bersifat diakronik maupun sinkronik.

4. Hal khusus dalam penelitian ini, meliputi segi-segi yang melatarbelakangi pembentukan wujud visual pada desain keraton Surakarta yang dianggap sebagai artifak yang mewakili budaya Jawa. Beberapa hal yang terkait dalam pembentukannya, sebagai berikut:

a. Di dalam khazanah Kebudayaan Jawa, suatu produk atau artifak memiliki suatu kekhasan, karena mengandung empat unsur, yaitu: Gegebengan (keyakinan); Kaweruh-werah (wawasan), Ngelmu (kemampuan yang bersifat mendayagunakan kaweruh agar memberikan makna pada alam dan seisinya), serta Simbol yang merupakan peragaan lahiriah sebagai rangkuman dari Gegebengan, Kaweruh serta Ngelmu.

b. Seni dalam bahasa Jawa tidak terformulasi sebagai suatu konsep, melainkan identik dengan karya yang intinya adalah perbuatan, tindakan, motif dan maksud (makarya). ${ }^{3}$ Keindahan bagi orang Jawa

\footnotetext{
${ }^{3}$ Makarya merupakan suatu kegiatan yang didasarkan pada buddhi, tidak hanya merupakan suatu respons
} 
bukan merupakan pengalaman sensual yang melibatkan rasa ke dalam keadaan rahayu yang membuatnya utuh dan selamat. ${ }^{4}$ Untuk menjadi suatu artifak, karya memerlukan proses sosialisasi dalam rangka penerimaan oleh masyarakatnya. Keselarasan terkait dengan dua kaidah yang menentukan bentuk konkrit dalam pola interaksi masyarakat Jawa, yaitu: prinsip kerukunan dan prinsip hormat.

\section{$3 \quad$ Keraton dan Pusat Kerajaan}

Gaya arsitektur dan tata letak keraton ini didasari oleh prinsip yang berakar pada kosmologi Hindu-Jawa. Gunung Mahameru yang keramat pada pusat alam semesta dilambangkan dengan pendopo (balai pertemuan) dan taman dalem. Rangkaian Bangunan dan halaman yang terpencar dari pusat melambangkan daratan dan lautan. Berbagai bangunan dipisahkan oleh dinding yang tinggi dan pintu gerbang simbolis yang bukan saja menjadi lambang perbedaan tingkat dalam sistem kosmologi, tetapi juga berfungsi sebagai penjaga yang memiliki kekuatan fisik dan batin.

Pandangan tentang keraton sebagai pusat keramat kerajaan menentukan paham yang dianut suatu negara Jawa, menurut filsafat politik Jawa, negara paling

\footnotetext{
atau jawaban dari kebutuhan. Buddhi adalah suatu kekuatan mencipta, daya cipta, daya ingat, buah pikiran, ingatan, kecerdasan, kepekaan, akal, dan hati, hasilnya berupa karya yang disertai buddhiracana (hasil rekaan manusia). Melalui daya-daya inilah manusia mampu membuka alam menjadi dunia. Berkarya bagi orang Jawa erat kaitannya dengan pengertian "memayu ayuning buwana". Artinya, tidak ada maksud berkarya yang tidak menghaturkan keindahan dunia. Hatur (menghaturkan) memiliki pengertian ganda yaitu menghadirkan, menampilkan dan mempersembahkan sesuatu secara khidmat dan hormat. Sesuatu yang sering diasosiasikan dengan berbagai kekuatan di luar manusia (sesuatu yang transenden). Aspek rasa dalam khasanah Jawa, paralel dengan pengertian rasa dari Aristoteles. Baginya tujuan tertinggi manusia adalah eudaimonia (kebahagiaan), sedangkan etika Jawa mengarahkan manusia pada suatu jalan yang menjamin pengalaman keselamatan dan ketenteraman hati, oleh karenannya rasa selamat dan ketentraman hati dengan perincianperinciannya yang berbeda-beda sebagai paham Jawa tentang eudaimonia (Eudaimonia Aristoteles dan rasa selamat Jawa mempunyai kesamaan, bahwa mereka tidak merupakan tujuan instrumental, bukan hanya merupakan alat untuk mencapai tujuan, melainkan membawa maknanya dalam dirinya sendiri). Perbedaan keduanya adalah bahwa Aristoteles menganalisa manusia terpisah dari seluruh lingkungannya atau pada dirinya sendiri, sebagai individu dengan relasi-relasi sosialnya, sedangkan dalam pengalaman Jawa manusia sejak semula merupakan kesatuan dengan masyarakat dan kosmos. Oleh karena itu bagi Aristoteles eudaimonia terdiri dalam pelaksanaan kegiatan-kegiatan atau bentuk-bentuk hidup yang khas bagi manusia (bentuk hidup yang praktis dan yang teoretis), sedangkan keadaan selamat dan ketenteraman hati direalisasikan dengan menempatkan diri dalam keselarasan dengan masyarakat dan kosmos.

4 Konsep-konsep yang berkembang dari rahayu, adalah hinaywan (disetujui, disepakati) dan pamahayu (perlindungan, pertolongan). Keindahan bagi orang Jawa bukanlah pengalaman sensual yang tidak melibatkan rasa ke dalam kondisi atau keadaan rahayu. Keindahan dalam pengertian rahayu terkait dengan kejadian yang membuatnya utuh dan selamat, sehingga hadir dan tersedia. Hayu atau rahayu sendiri bukanlah sifat atau keterangan, namun sebagai substantif dalam arti kebajikan, keselamatan, keindahan, keutuhan. Dengan tidak merujuk pada sifat atau karakteristik yang dimiliki oleh sesuatu karya, maka pengertian konsep rahayu adalah keadaan selamat, sentosa, dan seterusnya, yang merujuk pada peristiwa yang sudah selesai.
} 
padat berada di pusat, yang berdekatan dengan tempat Raja. Keraton dikelilingi oleh ibukota seperti cincin, di mana keluarga-keluarga abdi dalem tinggal. Sistem kerajaan Jawa pada dasarnya hanya terdapat ibukota dan daerah. Ibukota terdiri atas keraton, apa yang tinggal di sekelilingnya berfungsi memberikan pelayanan terhadap ibu kota. Di daerah Raja diwakili oleh pegawai-pegawai yang dapat dipindahkan dari tempat yang satu ke tempat yang lain dan jabatannya tidak dapat diwariskan (Keadaan itu baru mulai berubah di bawah pemerintahan kolonial Belanda).

Begitu tingginya peran Raja pada sistem budaya Jawa, sehingga harus memegang teguh prinsip dan konsepsi ratu binathara, yang tersirat pada kalimat: "gung binathara bau dhendha nyakarawati, ber budi bawa le(k)sana ambeg adil para marta. Empat sendi dasar dari konsepsi ini, yaitu: pertama dan kedua menunjukkan kekuatan (bau dhendha) sebagai penguasa dunia (ayakrawati), dua dimensi lainnya berisi penjelasan bagaimana seorang Raja harus melaksanakan kekuasaan yang dimilikinya itu, disebutkan, bahwa ia harus ber budi yang berani, budi baiknya seakan-akan terus mengalir karena penuhnya (luber), bawa le(k)sana berarti memegang teguh kata-katanya, dan ambeg adil paramarta mengandung arti bersifat adil serta bermurah hati. Keempat sendi tersebut saling melengkapi, sehingga mencapai suatu keseimbangan. ${ }^{5}$

Ratu binathara mengenal beberapa tingkatan. Disebut ratu binathara utama, jika Raja benar-benar melaksanakan tindakan ber budi bawa le(k)sana ambeg adil paramarta. Jika Raja kurang dapat melaksanakan darma ini, maka ia dimasukkan pada golongan di bawahnya, yaitu tingkat madya. Jika pemerintahannya sama sekali menyalahi darma tersebut di atas, maka Raja itu digolongkan pada tingkat nistha. Pegangan untuk Raja atau penguasa agar dapat digolongkan pada kategori utama antara lain terdapat dalam serat yang disebut oleh Koentjaraningrat, yaitu NitipRaja, Kojajahan, dan Asthabrata.

Masyarakat Jawa percaya bahwa kekuasaan para pimpinan dinasti Jawa merupakan anugerah dari Tuhan. Raja dianggap sebagai pemimpinan spiritual, politik dan sosial di kalangan masyarakat Jawa, sedangkan kraton sebagi pusat

\footnotetext{
${ }^{5}$ Bagi rakyat Jawa, keraton itu bukan hanya suatu pusat politik dan budaya, melainkan merupakan pusat keramat dari suatu kerajaan. Keraton adalah tempat Raja bersemayam, dimana Raja merupakan sumber kekuatan-kekuatan kosmis yang dianggap dapat membawa ketenteraman, keadilan, dan kesuburan. Segala kekuasaan dan hukum berasal dari pribadi Raja, sehingga Raja merupakan sumber kedaulatan. Kekuasaan dalam pemahaman memiliki makna yang berbeda dengan makna power dalam bhs.Inggeris, yang berkaitan dengan hal-hal fisik. Sebagai contoh kekuatan alam merupakan kekuasaan yang merepresentasikan ungkapan Ilahi tanpa bentuk. Kekuasaan bukanlah suatu gejala sosial yang berbeda dari kekuatan-kekuatan alam, melainkan ungkapan kekuatan kosmis yang memenuhi seluruh kosmos.
} 
simbolik dan fisik alam semesta. Gaya arsitektur dan tata letak keempat kraton ini didasari oleh prinsip yang berakar pada kosmologi Hindu-Jawa. Gunung yang keramat pada pusat alam semesta dilambangkan dengan Pendopo (balai pertemuan) dan Taman Dalem. Rangkaian Bangunan dan halaman yang terpencar dari pusat melambangkan daratan dan lautan (jambudwipa), berbagai bangunan dipisahkan oleh dinding yang tinggi dan pintu gerbang simbolis yang bukan saja menjadi lambang perbedaan tingkat dalam sistem kosmologi, tetapi juga berfungsi sebagai penjaga yang memiliki kekuatan fisik dan batin. Dengan demikian keraton sebagai pusat kegiatan dan tempat tinggal Raja, merupakan representasi dari sifat-sifat yang disebut diatas, baik dari segi fungsi maupun dari segi simbolis yang pada akhir terejawantahkan pada wujud visual keraton.
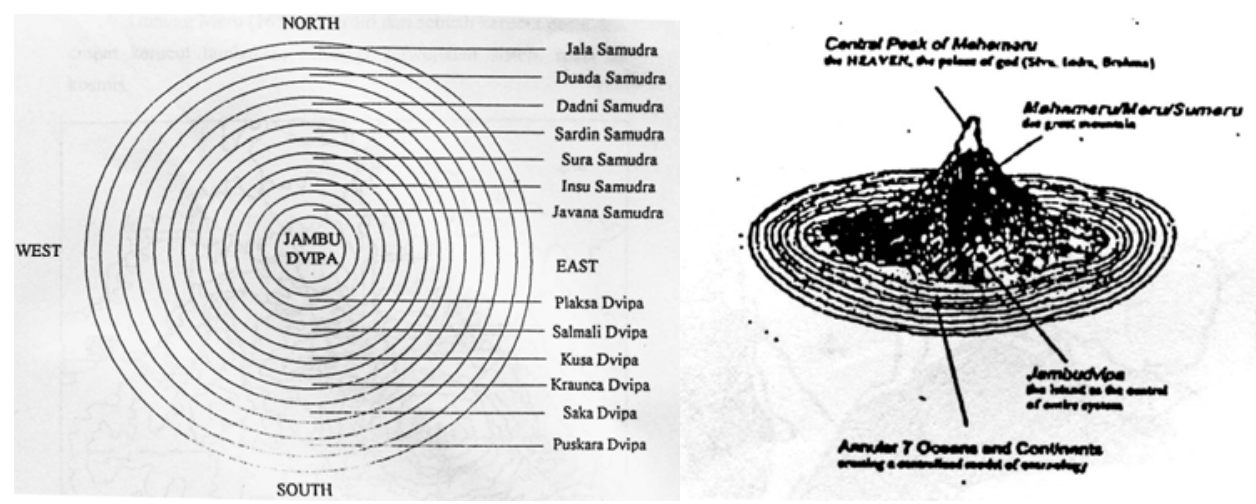

Gambar 1 Sistem Kosmologi Hindu (Sumber: Denys Lombard, 1996: 97).

Kata estetika selalui dikaitkan dengan 'kata indah', di balik ungkapan tersebut tersembunyi banyak pertanyaan, antara lain; apa dan yang bagaimanakah yang indah itu? Keindahan secara umum terdapat pada objek atau subjek dari suatu benda. ${ }^{6}$ Beberapa filsuf Kristiani seperti Santo Augustinus (354-430) dan Thomas Aquinas (1225-1274) berpendapat bahwa 'kebenaran' dan 'keindahan' adalah sinonim. Pemahaman yang jelas mengenai kebenaran yang dalam hal ini adalah kebenaran Ilahiah, yang akan menghasilkan persepsi terhadap keindahan, dan usaha untuk mengekspresikan kebenaran ini dalam seni akan menghasilkan bentukbentuk yang indah.

6 Bagi Plato keindahan terdapat di dalam pikiran murni manusia yang ideal sehingga tidak mungkin dapat diperoleh di dunia yang wadaq ini, baik pada kategori objek maupun subjek. Keindahan tidak tergantung pada rasa suka atau tidak suka secara individual, melainkan atas pemahaman intelektual terhadap sesuatu benda atau hal tertentu. 
Santo Augustinus mendefinisikan keindahan sebagai kesatuan bentuk (omnis pulcritudinis forma unitas est) dan Thomas Aquinas mempersyaratkan tiga hal untuk bisa disebut indah, yaitu: (1) adanya integritas atau perfeksi; (2) proporsi yang tepat atau harmoni; dan (3) adanya kejelasan. Selanjutnya pada jaman modern, Herbert Read menambahkan bahwa beauty is a unity of formal relations among our sense-perceptions. ${ }^{7}$ Tiga-tiganya menempatkan keindahan pada objek. Alexander Gottlieb Baumgarten (1714-1762) seorang filsuf Jerman, dalam disertasinya membedakan adanya tiga kesempurnaan di dunia ini, yaitu: (1) Kebenaran (das Wahre), ialah kesempurnaan yang bisa ditangkap dengan perantaraan rasio; (2) Kebaikan (das Gute), kesempurnaan yang ditangkap melalui moral atau hati nurani; dan (3) Keindahan (das Schöne), yaitu kesempurnaan yang ditangkap dengan indera (perfectio cognitionis sensitivae, qua talis). ${ }^{8}$ Ini berarti bahwa berlainan dengan pandangan lama, keindahan tidak dimuati lagi dengan kebaikan maupun kebenaran karena fasilitasnya berbeda, dan dengan pandangannya bahwa keindahan adalah kesempurnaan yang ditangkap dengan indera ini, maka lahirlah filsafat keindahan yang disebut 'Estetika' yang berasal dari bahasa Yunani 'aisthasis' yang artinya persepsi. Bagi Baumgarten estetika adalah the science of perceptual cognition.

Dalam kaitan pemahaman terhadap nilai-nilai keindahan, secara umum khasanah Jawa menempatakan aspek pemeliharaan keselarasan dalam masyarakat dan alam raya sebagai nilai tertinggi. Dalam hubungan ini terdapat dua kategori kunci yang dipergunakan dalam etika Jawa untuk mengatur semua unsur lahir dan batin, yaitu kategori alus (halus) dan kasar. Kata 'halus' merupakan istilah yang mengungkapkan kehalusan suatu permukaan, kehalusan dalam kelakuan, kepekaan, ketampanan, kesopanan, dan sebagainya, sedangkan 'kasar' adalah segala-galanya yang berlawanan dengan halus.

Halus adalah tanda keselarasan yang sempurna. Apabila masyarakat berada dalam keadaan selaras maka semuanya berjalan dengan baik, keselarasan alam nampak dalam kesuburannya, tak ada malapetaka dan bencana, kekuatankekuatannya mengalir dengan tenang, tanpa menimbulkan perhatian, mirip dengan putaran roda sebuah generator raksasa yang karena kecepatan dan kehalusannya tak lagi kelihatan gerakannya. Halus adalah perilaku seseorang yang sudah mampu mengontrol kejasmaniannya dan telah mampu mengatur batinnya sehingga ia mencapai rasa yang benar. Sebaliknya kelakuan kasar adalah tanda kekurangan kontrol diri dan kekurang-matangan, dengan demikian halus merupakan tanda dari kekuatan, kasar merupakan tanda dari kelemahan. Pasangan kata halus-kasar adalah tolak ukur orang Jawa untuk

\footnotetext{
7 Dalam: Read, H. (1972: 18).

8 Dalam Leo Tolstoy (1960 : 25)
} 
menilai semua gejala dalam lingkungannya, karena halus merupakan hakekat kekuatan-kekuatan kosmis yang berada di belakang gejala-gejala lahiriah maka kehalusan merupakan tanda bahwa seseorang telah menembus sampai kepada tingkat realitas yang sebenarnya. ${ }^{9}$

Sebagai contoh adalah Arjuna yang merupakan tokoh yang paling penting dalam konteks Wayang Jawa, meskipun memiliki kesaktian yang sangat tinggi tidak digambarkan berbadan kekar dan besar. Ini menggambarkan bahwa kekuatan lebih bersifat 'dari dalam' dan bukan sesuatu yang nampak 'dari luar'. Ksatria ini digambarkan sebagai sosok yang halus dan lembut. Dalam beberapa pertunjukan wayang orang di Jawa, tokoh Arjuna selalu diperankan oleh wanita

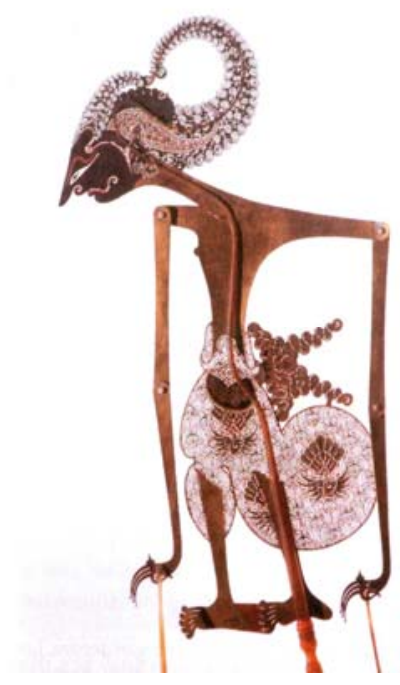

Gambar 2 Tokoh Arjuna dalam bentuk wayang kulit.

Halus dan kasar merupakan kategori estetis, karena pada dasarnya sesuatu yang halus adalah indah dan sesuatu yang kasar merepresentasikan rupa yang

\footnotetext{
${ }^{9}$ Memperdalam rasa berarti membuatnya menjadi lebih halus, sebaliknya semua unsur kasar merupakan tanda bahwa seseorang belum menembus sampai ke realitas yang sebenarnya. Kehalusan adalah tanda eksistensi yang benar, serta menunjukkan keselarasan dan kekuatan batin, sementara kekasaran memperlihatkan kekurang-selarasan dan tidak adanya kekuatan batin. Dengan demikian kehalusan merupakan suatu kriteria yang mempunyai 'relevansi moral'. Makin halus sesuatu, makin baik dan benar, dan makin kasar sesuatu, makin salah dan buruk, maka dari itu moral dapat diukur dari segi halus atau kasarnya kelakuan tersebut, atau apakah kelakuan itu lebih memperhalus atau memperkasar suatu keadaan. Penilaian menurut tolok-ukur halus dan kasar sebetulnya sama dengan penilaian dari segi keselarasan dan dari segi realitas batin yang sebenarnya.
} 
buruk atau jelek. Sesuatu yang baik hanya dapat terlaksana dalam keadaan keselarasan sempurna, dan karena yang buruk selalu merupakan gangguan terhadap keselarasan itu, sehingga langsung dapat dimengerti bahwa yang baik itu indah dan yang buruk kelihatan jelek. Sesuatu yang indah itu baik karena merealisasikan keselarasan, dan gangguan terhadap keselarasan nampaknya jelek, dalam bahasa Jawa untuk kata 'baik' (becik) juga dipakai dalam arti 'indah', walaupun kata indah juga diungkapkan dengan kata tersendiri (endah). Seperti dalam bahasa Indonesia (demikian pula dalam bahasa Jawa), tidak ada kata khusus untuk suatu pandangan yang jelek, hanya ada kata ala (juga elek), yang berarti buruk, baik dalam arti estetis maupun dalam arti moral. ${ }^{10}$

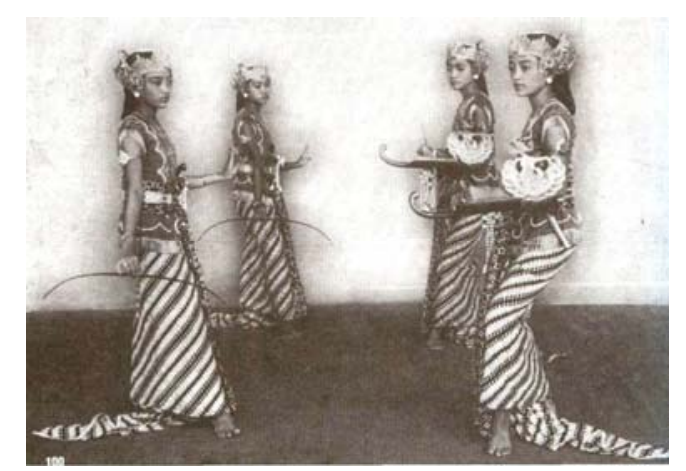

Gambar 3 Perujudan estetika pada tari Serimpi (Sumber: Claire Holt, 2000:153).

Tari Serimpi yang lembut merupakan puncak dari sebuah aktifitas pertempuran yang terstilasikan dan tidak ada yang menang. Pertama dengan menggunakan senjata keris, kemudian dengan busur-busur kecil dan anak panah. Interpretasi oleh Helsdingen pada bukunya Hecht verboden in lief en leed, Amsterdam-New York, Board Elsavier, 1946 (yang dikutip Holt, 2000, h. 148-153) adalah bahwa para penari tersebut menggambarkan dua orang bidadari yaitu Supraba dan Wilutama, yang terlibat perang-perangan untuk menghibur para dewa. Interpretasi lain menyatakan merupakan perang antara dua orang puteri yang terlibat dalam sebuah intrik diseputar Raja yang berkuasa di Arab. Salah seorang puteri yang terdorong cinta merencanakan membebaskan kekasihnya dari penahanan, tetapi mecurigai yang lainnya karena dianggap memata-matai dan akan menghianatinya, sehingga terjadilah peperangan. Yang menarik disini,

\footnotetext{
${ }^{10}$ Baik-Benar-Indah merupakan suatu pengertian yang tidak terpisah-pisah, sebagai contoh baik (becik) juga mempunyai pengertian yang sama dengan indah (endah), walaupun masing-masing mempunyai istilah yang tersendiri. Dalam konteks alus-kasar dapat dikategorikan: Baik-Buruk; Bagus-Jelek.
} 
adalah bahwa ekspresi dari peperangan tersebut dibawakan dengan gerakan yang sangat lamban sebagaimana halnya tari Bedhaya. Tari ini selalu dibawakan oleh para puteri dari adipati yang sedang memerintah.

Kesadaran itu pada orang Jawa bersifat spontan dan kuat, sehingga mereka berpendapat bahwa rasa kekecewaan dapat menyebabkan orang menjadi sakit. Melalui rasa orang Jawa memahami bahwa yang paling cocok, sehat dan sesuai baginya ialah untuk tidak mengejar kepentingan-kepentingan sempitnya sendiri saja, jadi sikap sepi ing pamrih. Sekaligus ia memahami bahwa setiap orang mempunyai tugasnya dalam dunia, bahwa yang paling baik, paling menenangkan dan paling sehat bagi semua pihak ialah apabila mereka masingmasing memenuhi kewajiban-kewajiban mereka, jadi mempunyai sikap rame ing gawe.

Etika Jawa menawarkan suatu maksimum kepada pemenuhan eksistensi. Siapa yang hidup menurut petunjuk-petunjuk etika Jawa, akan merasa slamet dan menikmati katentremaning ati (ketenteraman hati). Manusia yang bijaksana akan hidup sesuai dengan norma-normanya, dalam kerangka etika Jawa pemenuhan kewajiban-kewajiban merupakan cara hidup yang rasional. Menurut paham Jawa, manusia menemukan rasa selamat dalam keselarasan masyarakat yang sekaligus berarti bahwa ia juga selaras dengan kekuatankekuatan kosmos. Segi sosial bagi orang Jawa merupakan faktor menentukan dalam usahanya untuk mencapai ketenteraman hati. Etika Jawa mengandaikan bahwa seseorang tidak akan dapat memenuhi tuntutan-tuntutannya apabila belum sampai ke pengertian itu ("durung ngerti').

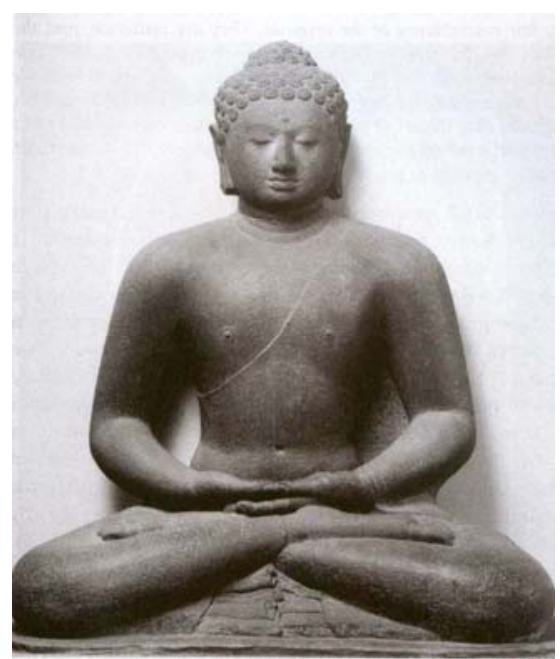

Gambar 4 Perujudan Patung Budha abad IX dalam viasualisasi Jawa (Sumber: Soedarso SP, 2006:19, (Jan Fontein, The Sculpture of Indonesia). 
Soedarso SP., dalam bukunya yang berjudul Trilogi Seni, Penciptaan Eksistensi dan Kegunaan Seni (2006:18-19), menyatakan bahwa para seniman Indonesia masa lampau (khususnya Jawa), tidak pernah melukiskan bentuk-bentuk di alam ini seperti adanya. Mereka lebih tertarik untuk melukiskan sesuatu yang lebih dalam sifatnya: baik tangkapan kehalusan jiwa maupun pandangan religiusnya; dan bentuk-bentuk yang dilahirkannya selalu merupakan simbol-simbol yang kasatmata dari apa-apa yang tidak terlihat itu. Patung-patung Budha dari Borobudur, misalnya, bukanlah merupakan gambaran orang atau dewa yang sedang bersamadi, melainkan gambaran ketenangan, keluhuran, atau kesempurnaan Sang Budha. Contoh tersebut kebetulan diambil dari yang paling "realistik" di antara seni Indonesia masa lalu. Maka tidaklah mengherankan bahwa keadaan yang dimaksud di atas akan jauh lebih tampak pada bentuk visual wayang kulit.

Menarik untuk mengungkap pengamatan Raffles di awal abad XIX yang menyatakan:

The Javanese have made no progress in drawing or painting; nor are there any traces to be found of their having, at any former period of their history, attained any proficiency in this art. They are not, however, ignorant of proportions or perspective, nor are they insensible to the beauty and effect of the productions of other nations. Their eye is correct and their hand steady, and if required to sketch any particular object, they produce a very fair resemblance of the original. They are imitative, and though genius in this art may not have yet appeared among them, there is reason to believe that, with due encouragement, they would not be found less ingenious than other nations in a similar stage of civilization. They have a tradition, that the art of painting was once successfully cultivated among them, and a period is even assigned to the loss of it; but the tradition does not seem entitled to much credit. ${ }^{11}$

Raffles menyatakan bahwa tradisi seni gambar dan seni lukis di Jawa tidak berkembang walaupun tidak ada kendala fisiologis maupun psikis dari masyarakat pendukungnya. Sejak jaman Prasejarah sampai datangnya pengaruh Barat di Indonesia tidak pernah ada sesuatu karya yang mengarah pada penangkapan alam secara visioplastik ${ }^{12}$. Pendapat Raffles di atas, dengan tegas menyatakan bahwa karya tersebut sama sekali tidak ditimbulkan, karena orang-orang Jawa bermasalah dengan kemampuan mata atau tangannya,

\footnotetext{
11 Lihat: Raffles, T.,S. (1978: 472-473).

12 Visioplastik merupakan sebuah istilah psikologi yang digunakan oleh Max Verworn mengenai seni primitif yang kemudian dikutip oleh Soedarso SP,2006, h.15-24). Lawan ideoplastik, sebuah istilah yang diperkenalkan oleh Max Verworn dalam bukunya Zur Psychologie der primitiven Kunst (1917), yang digunakan untuk menamai gambar anakanak dan suku-suku primitif yang biasa menggambarkan apa yang mereka ketahui tentang objeknya, bukan apa yang dilihatnya. Jadi visioplastik adalah gambar atau lukisan yang memperturutkan apa yang nampak oleh mata.
} 
ataupun karena tidak menghiraukan akan proporsi dan perspektif serta tidak peka akan keindahan dan efek-efek lain seperti yang ditemukan oleh bangsabangsa lain. Keberadaan karya yang tidak visioplasik, seperti wayang kulit Jawa Timur dari masa Majapahit sampai dengan wayang kulit Jawa Tengah masa kini yang dipengaruhi oleh masuknya agama Islam ke Indonesia.

\section{$4 \quad$ Nilai Estetik Keraton Surakarta}

Berdasar penelitian yang telah dilakukan (2001-2006), banyak nilai-nilai religius dan simbolik yang ditemukan dalam berbagai tempat di Keraton Surakarta. Hal ini menandakan bahwa keraton menaruh perhatian yang sangat besar untuk pengembangan kehidupan religius dan spiritual. Para penguasa Jawa sejak lama telah mempertimbangkan berbagai peran dalam berbagai hal. Mereka dihormati sebagai pemimpin perang, sebagai pemegang kendali otoritas administratif tertinggi serta sebagai perwakilan dari Tuhan. Karaton, di satu sisi merupakan tempat hunian, tetapi disisi lain diperlukan untuk memenuhi berbagai aktivitas yang dilakukannya. Keraton merupakan cerminan dari mikrokosmos (dalam hubungannya dengan rakyat) dan makrokosmos (dalam hubungannya dengan Tuhan). Bangunan keraton direncanakan dalam upaya memperkuat karisma dari penguasa yang diyakini memiliki kuasa yang bersifat ke-Illahian.

\subsection{Sistem Denah dan Bangunan}

Sistem denah dan bangunan dapat dilihat, seperti: nyipati wewangun toto lahir, sinartan dhamang dumateng pagedhong pikajeng, manunggaling kang agal lan alus, merupakan pertemuan antara fisis dan metafisis, antara logika dan non logika, yang membedakan antara sesuatu yang halus dan kasar, antara wadaq dan pikiran. Sistem bangunan menyerupai tipologi suatu struktur yang merupakan lambang atau gambaran dari tubuh manusia, mulai dari atas sampai ke bawah; Sistem denah yang mempunyai urutan sangat terstuktur, melambangkan suatu perjalanan yang spiritual dalam mencari kesatuan (manunggal) dengan Pencipta, selain itu juga melambangkan tahapan pengendalian emosi, serta perjalanan usia dari kelahiran, masa muda, masa tua dan akhir dari kehidupan.

\subsection{Pajupat, Arsitektur Suluk, dan Jagad Walikan}

Poros simbolis dari desain kompleks keraton, dapat ditelusuri mulai dari arah utara sampai ke selatan, dan diatur berdasarkan konsep filosofis dari Sangkan yang paraning dumadi, jumbuhung kawulo Gusti dan Keblat papat. Kompleks keraton juga berorientasi pada pajupat, sebuah konsep yang diyakini dapat memelihara getaran spiritual, sehingga tercipta keseimbangan antara makrokosmos dan mikrokosmos. Pajupat, memiliki empat kekuatan yang 
mendukung dan merupakan tempat yang mampu menggali kuasa-kuasa 'metafisis'. Konsep denah dari kompleks keraton yang dibuat mengikuti sepanjang garis lurus poros aksis dan dipercaya memiliki kekuatan yang disebut Krendowahono. Empat kekuatan alam tersebut berasal dari hutan lebat yang berada di utara; matahari terbit dan Gunung Lawu di timur; Samudra yang besar di selatan; dan Gunung Merapi dan Gunung Merbabu disebelah barat.

Keraton dibuat melalui keteraturan keindahan dan keselarasan, yang dikenal sebagai sebagai Arsitektur Suluk. Susunan ruang didasari proses pelatihan spiritual untuk mencapai kesempurnaan hidup. Ciri-cirinya didasarkan pada pengorganisasi unsur-unsur pembentuknya, seperti: rancangan kompleks, ruang, warna, bentuk, gaya bangunan, unsur dekorasi, serta ragam hias. Secara umum desain Keraton Surakarta memancarkan suatu keindahan yang khusus, seperti: kaitan antara bentuk dibalik makna, kaitan bentuk dengan sesuatu yang tenang tetapi penuh dengan tekanan dari simbol-simbol tertentu. Dalam khasanah Jawa, pencapaian arsitektur dengan bentuk yang demikian hanya dapat tercapai dengan mengakui adanya kebesaran dari Kang Murbeng Dumadi (Tuhan).

\subsection{Wujud Visual Keraton dan Watak Estetika}

Peran Raja yang sangat tinggi pada sistem budaya Jawa tersirat pada konsepsi ratu binathara, yaitu: "gung binathara bau dhendha nyakarawati, ber budi bawa le(k)sana ambeg adil para marta, yang memiliki empat sendi dasar, yaitu: pertama dan kedua menunjukkan kekuatan (bau dhendha) sebagai penguasa dunia (ayakrawati), dua dimensi lainnya menyatakan bahwa seorang Raja dalam melaksanakan kekuasaan harus ber-budi (budi baiknya seakan-akan terus mengalir karena penuhnya atau luber), bawa le(k)sana berarti memegang teguh kata-katanya, dan ambeg adil paramarta mengandung arti bersifat adil serta bermurah hati. Keempat sendi tersebut saling melengkapi, sehingga mencapai suatu keseimbangan. Keraton sebagai suatu karya merupakan representasi dari raja yang memiliki nilai-nilai ratu binathara, maka dalam pewujudannya keraton memiliki watak-watak tertentu, karena ia dianggap sebagai sesuatu yang memiliki sifat-sifat dari kehidupan (dengan meminjam peristilahan Yunani bahwa suatu karya ditinjau dari sudut kategorisasinya dapat dilihat pada tiga perwatakan, yaitu : watak transenden estetika, watak keberaturan estetika, serta watak pragmatik estetika).

Usaha-usaha untuk menciptakan getaran spiritual guna mendukung pamor dan karisma Raja selaku penguasa dilakukan dengan penggambaran secara simbolik pada bangunan serta komponen-komponen pendukungnya dari pemahaman Jawa tentang proses terjadinya alam semesta. Hal ini muncul pada simbolsimbol visual yang jelas, seperti, ketika seseorang pergi ke arah selatan, dari Gapuro Gladhag melalui gerbang Srimanganti yang melambangkan hubungan 
matahari, bulan, dan bintang. Selanjutnya menuju ke arah selatan sampai pada Gapuro Gadhing Kidul, akan terlihat seperti 'dunia yang dibalikkan', jagad walikan, suatu konsep hidup Jawa dari serat DewaRuci (kisah pencarian diri menuju kesempurnaan hidup).

Pendopo Ageng, Pelataran Kedhaton dan Dalem Ageng, secara simbolis menceritakan proses kelahiran, melalui gerbang Srimanganti Kidul digambarkan secara simbolis lambang phalus (lingga) dan Yoni. Area Magangan melambangkan periode seseorang untuk magang dan belajar (periode usia muda). Area Kamandungan Kidul dan Supit Urang Kidul melambangkan simbol dari lepasnya kedua belah kaki dari badan yang berarti manusia harus berbuat lebih banyak berkorban untuk mencari kebaikan, ke arah selatan melintasi Gapuro Gadhing, seseorang akan tiba di gerbang akhir, ketika seseorang mencapai status dihormati (tempat di mana seseorang yang telah melaksanakan hidupnya), akan kembali ke titik dari asal, dan pada akhirnya bertemu Sang Pencipta, Sangkan Paraning Dumadi.

\subsection{Wujud Visual Keraton dan Akulturasi}

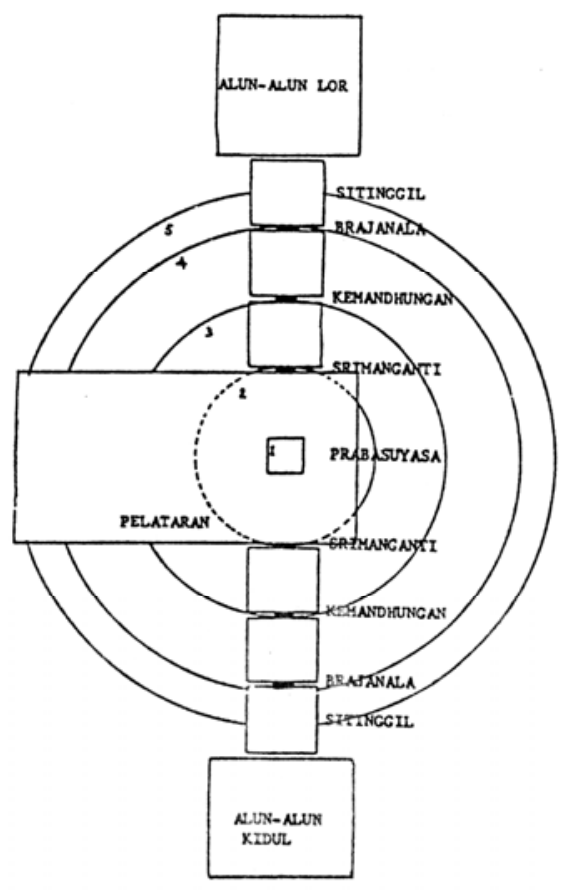

Gambar 5 Sistem Denah Konsentris Keraton Jawa (Sumber: Denys Lombard, 1996 : 197). 
Keraton Surakarta sebagai sekumpulan ide-ide (ideas) yang terlembagakan tersebut berasal dari keyakinan masyarakat Jawa yang percaya bahwa Raja (merupakan perwakilan dari Tuhan) sehingga dianggap sebagai pemimpinan spiritual, politik dan sosial di kalangan masyarakat Jawa. Ide tersebut terlembagakan pada arsitektur keraton sebagi pusat simbolik dan fisik alam semesta. Gaya arsitektur dan tata letak keempat keraton ini didasari oleh prinsip yang berakar pada kosmologi Hindu-Jawa. Gunung yang keramat pada pusat alam semesta dilambangkan dengan Pendopo (balai pertemuan) dan Taman Dalem.

Keraton Surakarta sebagai representasi dari suatu kompleks aktivitas, dibuat melalui keteraturan keindahan dan keselarasan sebagaimana nilai-nilai yang ada pada etika Jawa. Dalam hubungan ini terdapat dua kategori kunci yang dipergunakan dalam etika Jawa untuk mengatur semua unsur lahir dan batin, yaitu kategori alus (halus) dan kasar.

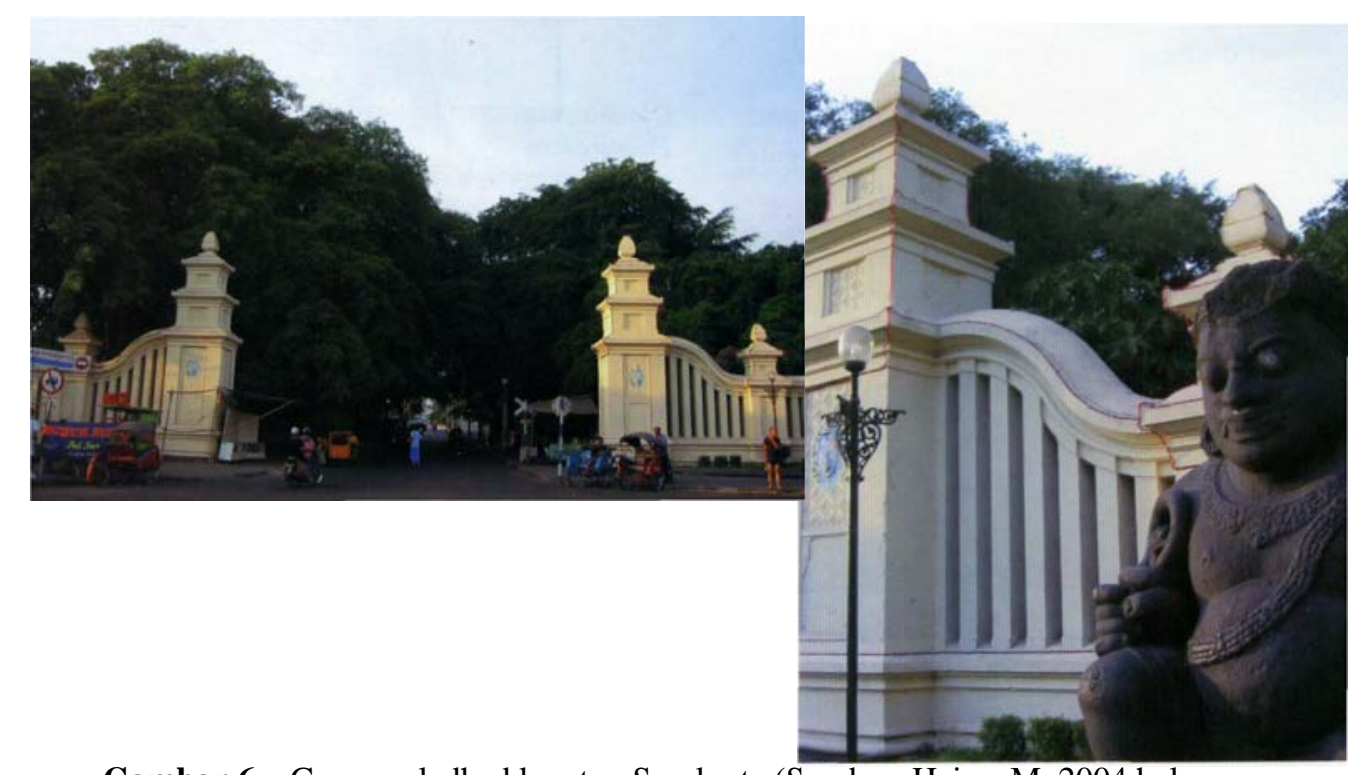

Gambar 6 Gapura gladhad keraton Surakarta (Sumber: Heins, M. 2004 hal 105-106)

Halus adalah tanda keselarasan yang sempurna. Keraton Surakarta merupakan tempat dimana 'makna' diobyektifikasikan dalam berbagai benda atau bagian ruang yang sepenuhnya dihasilkan melalui 'practices' (tindakan-tindakan yang telah menjadi kebiasaan). Arsitektur keraton dibuat berdasarkan filosofi Jawa (Kawruh Kejawen) yang dilihat sebagai sesuatu yang memiliki wadah atau bentuk dan isi (yang merupakan representasi lahir dan bathin). Bentuk dan isi merupakan simbolisasi dari kesatuan dari mikrokosmos (dunia manusia yang 
sehari-hari) dengan makrokosmos (alam semesta sebagai dunia yang diluar kewenangan manusia). Keraton merupakan suatu wadah yang sarat dengan berbagai tanda dan simbol yang merupakan pedoman hidup bagi orang Jawa, sehingga konsep wadah atau bentuk arsitektur keraton merupakan implementasi dari nilai-nilai yang dikandung di dalamnya.

Dalam kasus implementasi visual wujud estetik Keraton Surakarta pada proses akulturasi ini terlihat dari beberapa aspek, sebagai berikut:

1. Landasan koseptual dalam pembentukan denah tapak keraton, yang berakar pada beberapa aspek, seperti: sistem lingkaran konsentris, sistem orientasi pada empat arah mata angin, sistem mancapat, sistem kosmologis (yang melibatkan nilai-nilai dan unsur-unsur: Hindu; Budha; Islam). Penentuan lokasi keraton yang melibatkan berbagai unsur, yaitu: ahli negara, pujangga, ahli agama dan kebatinan, kaum ningrat dan bangsawan serta pihak kolonial Belanda.

2. Meskipun terjadi beberapa kali proses cultur contact dalam kurun waktu lebih dari sekitar 300 tahun, namun pembentukan denah tapak Keraton Surakarta mengacu pada master plan yang embedded dalam budaya Jawa. Dengan susunan arsitektur terdiri dari berbagai ragam bentuk yang dikemas dalam visualisasi khas Jawa, untuk merepresentasikan tujuan hidup orang Jawa, yaitu menuju kesempurnaan dalam Manunggaling kawulo Gusti.
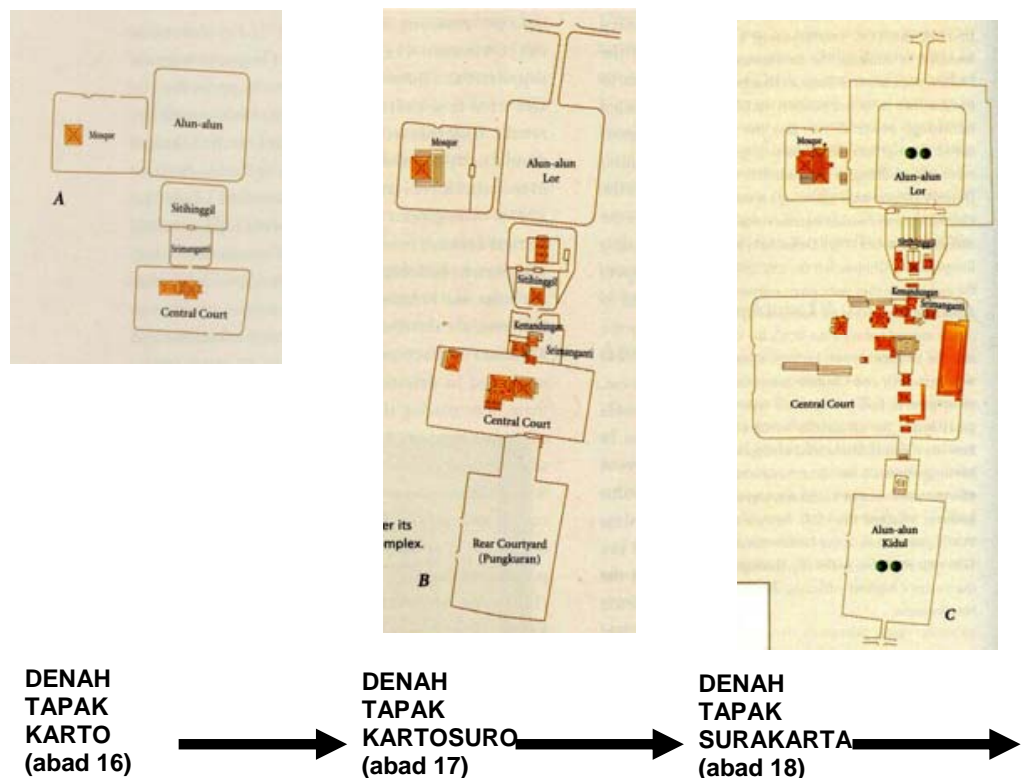

DENAH TAPAK SURAKARTA KARTO
(abad 16) (abad 17) (abad 18) (abad 20)

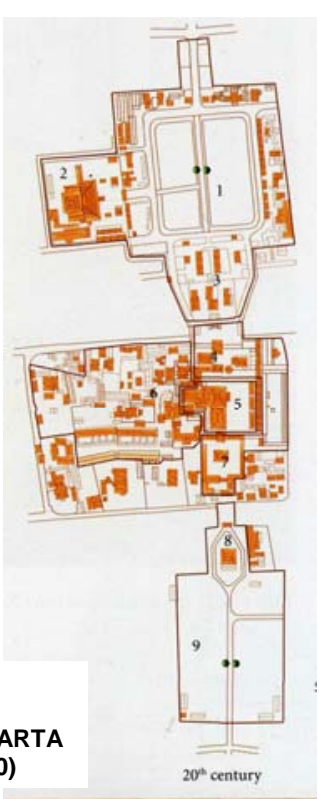


3. Pada bagian yang lebih detail, misalnya implementasi pada ragam hias yang memiliki makna yang berorientasi pada nilai Islam, tetapi kode visual yang ada masih mengacu pada bentuk-bentuk Hindu, Budha bahkan tradisional Jawa (seperti hukum-hukum Mancapat), pengaruh kolonial Belanda bersatu dalam konsep keselarasan.

\section{$5 \quad$ Kesimpulan}

Pertimbangan khusus yang digunakan dalam merancang keraton Surakarta, bertitik tolak pada kaidah-kaidah benar (good), baik (truth) dan indah (beauty), sebagai suatu kesatuan yang pada akhirnya merepresentasikan nilai-nilai keIllahian. Untuk memeliharanya sebagai suatu kesatuan yang utuh, tindakan orang Jawa terarah pada pemeliharaan keselarasan dalam masyarakat dan alam raya sebagai nilai tertinggi. Dalam hubungan ini terdapat dua kategori kunci yang dipergunakan untuk mengatur semua unsur lahir dan batin, yaitu kategori alus (halus) dan kasar. Pasangan halus-kasar adalah tolok-ukur orang Jawa untuk menilai semua gejala dalam lingkungannya. Halus dan kasar merupakan kategori etis dan estetis serta logis. Terminologi Jawa untuk "baik" (becik) juga dipakai dalam arti indah walaupun mempunyai kata tersendiri yaitu éndah. Tidak ada kata khusus untuk suatu pandangan yang jelek, hanya ada kata ala (juga élék), yang berarti buruk. Kesamaan istilah untuk menilai yang benar, baik dan indah memperlihatkan bahwa budaya Jawa bersifat holistik, oleh karenannya diduga bahwa tidak adanya peristilahan dan tolok ukur khusus tentang seni atau estetik, hal ini terkait dengan karakter yang khas dari budaya Jawa, yaitu sesuatu yang manunggal, tidak terpisah-pisah, yang merupakan konsep Sangkan Paraning Dumadi dan Manunggaling Kawulo Gusti.

Kompleks keraton berorientasi pada pajupat, sebuah konsep yang diyakini dapat memelihara getaran spiritual, sehingga tercipta keseimbangan antara makrokosmos dan mikrokosmos. Pajupat, memiliki empat kekuatan yang mendukung dan merupakan tempat yang mampu menggali kuasa-kuasa metafisis. Konsep denah dari kompleks keraton yang dibuat mengikuti sepanjang garis lurus poros aksis dan dipercaya memiliki kekuatan yang disebut Krendowahono.

Gaya pengungkapan visual Jawa pada Keraton Surakarta bersifat Ideo-Plastic, dan tidak bersifat Visio-Plastic (sebagaimana pemahaman 'Dunia Barat' tentang suatu obyek visual). Ditinjau dari segi pemaknaan, desain Keraton Surakarta merupakan: nyipati wewangun toto lahir, sinartan dhamang dumateng pagedhong pikajeng, manunggaling kang agal lan alus, yaitu bersatunya sesuatu yang fisis dengan yang metafisis, antara logika dan non logika, yang halus dan yang kasar, antara wadaq dan pikiran. Sistem bangunan mempunyai urutan yang terstuktur, melambangkan suatu perjalanan spiritual dalam mencari 
kesatuan (manunggal) dengan Pencipta. yang diatur berdasarkan konsep filosofis dari Sangkan paraning dumadi, jumbuhung kawulo Gusti dan Keblat papat.

Dalam konteks transformasi budaya, visualisasi obyek Keraton Surakarta dapat dikategorikan sebagai produk akulturasi. Hal ini terkait dengan karakteristik manusia Jawa yang mempunyai tujuan tertingginya adalah eudaimonia (kebahagiaan), yang menjamin keselamatan dan ketenteraman hati. Menurut paham Jawa, manusia menemukan rasa selamat dalam keselarasannya dengan masyarakat (yang sekaligus berarti bahwa ia juga selaras dengan kekuatan-kekuatan kosmos). Segi sosial bagi orang Jawa merupakan faktor menentukan dalam usahanya untuk mencapai ketenteraman hati. Etika Jawa mengandaikan bahwa seseorang tidak akan dapat memenuhi tuntutantuntutannya apabila belum sampai ke pengertian itu ("durung ngerti').

Dalam kaitan yang demikian, keraton yang dibuat melalui keteraturan keindahan dan keselarasan, serta didasari pada simbolisasi manusia Jawa untuk mencapai kesempurnaan hidup. Melalui pengorganisasian unsur-unsur pembentuknya, secara umum desain Keraton Surakarta merupakan totalitas dari kaitan bentuk dengan makna, kaitan bentuk dengan simbol, serta kaitan bentuk dengan sesuatu yang bersifat ke-Illahi-an. Sehingga dapat disimpulkan bahwa estetika Keraton Surakarta merupakan perpaduan antara kebaikan (nilai-nilai Sangkan Yang Paraning Dumadi) dengan keindahan sebuah arsitektur suluk. Hal ini sesuai dengan pernyataan Xenophon, bahwa 'kesempurnaan paripurna' adalah berpadunya yang indah dan yang baik (Der Vollendung in der Uberreinstimmung von Schonheit un Gute), dengan demikian desain Keraton Surakarta memiliki kandungan-kandungan yang bersifat universal.

Keraton merupakan salah satu model warisan budaya tinggi yang masih dimiliki hingga saat ini. Penelitian-penelitian secara khusus terhadap keraton merupakan langkah-langkah yang kondusif guna mencari morfologi arsitektur pemerintahan di Indonesia, hingga pada saatnya nanti, akan mempunyai konsep yang jelas, keunikan yang tinggi serta yang lebih penting landasan konseptual yang baik dan benar di dalam perancangannya.

Dalam upaya pengkayaan dan pelestarian budaya, proses menyalin teks asli, transliterasi, dan menerjemahkan secara khusus terhadap sumber-sumber tekstual tentang Budaya dan Estetika Jawa (prasasti, karya sastra, dan sumber berita berbahasa asing) masih dirasakan sangat perlu untuk dibuat salinan dalam huruf asli maupun dalam bentuk transliterasi ke dalam huruf latin, serta diterjemahan ke dalam bahasa Indonesia atau bahasa Inggris sehingga mudah ditelusuri kembali oleh para peneliti Indonesia sekarang dan masa depan. 
Penelitian terhadap suatu kagunan yang berakar pada tradisi, diharapkan dapat memberikan contoh tentang bagaimana dan seharusnya aspek nilai dan makna dari budaya diaplikasikan dalam wujud visual suatu rancangan (representasi). Kajian-kajian estetik sejenis memiliki prospek untuk dikembangkan lebih lanjut ke dalam teori-teori desain mutakhir. Di tengah-tengah tingginya percepatan dalam perkembangan dan perubahan konsep-konsep desain dewasa ini, upaya penggalian khazanah tradisi menjadi sangat penting, karena pada konsep tradisi-lah bergabungnya nilai-nilai kebenaran (sains), kebaikan (etik) dan keindahan (estetik), yang saat ini sudah jarang ditemukan. Penelitian sejenis dapat membuka wilayah penelitian yang lebih luas, khususnya dengan modelmodel estetika pasca kolonial. Hal-hal yang bersinggungan dengan studi-studi kebudayaan (cultural studies) akan menambah perbendaharaan keilmuan desain mutakhir, yang pada saatnya nanti akan memiliki nilai guna yang sangat tinggi (khususnya jika dikaitkan dengan pencarian nilai-nilai lokal yang memiliki dimensi universal).

\section{Daftar Pustaka}

[1] Dickie, G. 1971. Aesthetics, An Introduction, New York, Pegasus Traditions in Philosophy.

[2] De Jong. 1976. Salah Satu Sikap Hidup Orang Jawa, Yogyakarta, Penerbit Yayasan Kanisius.

[3] Casparis, J., G. 1950. Inscripties uit de Sailendra-tijd, Prasasti-prasasti dari Jaman Cailendra (Prasasti Indonesia I), Bandung, C. Nix \& Co.

[4] Greetz, H. 1961. The Javanese family. A Study of Kindship and Socialization, the Free Press of Glencoe.

[5] Heine, G. 1963. Conceptions of State and Kingship in Southeast Asia, Ithaca, New York, Cornell University Press.

[6] Holt, C. 2000. Melacak Jejak Perkembangan Seni di Indonesia, Bandung, Masyarakat Seni Pertunjukan Indonesia.

[7] Houben, J.H.V.1994. Keraton dan Kompeni, Surakarta dan Yogyakarta, 1830 - 1870, Yogyakarta, Bentang Budaya.

[8] Lombard, D. 1996. Nusa Jawa Silang Budaya, Bagian 1-2-3, Jakarta, PT. Gramedia.

[9] Raffles, T.S. 1978. The History of Java, Volume One, Oxford University Press, Kuala Lumpur, Oxford, New York, Melbourne, 472-473.

[10] Read, H. 1972. The Meaning of Art, New York, Praeger, 18.

[11] Sedywati, E. 1981. Pertumbuhan Seni Pertunjukan, Jakarta, Penerbit Sinar Harapan, hal 16-18.

[12] 1994. Pengarcaan Ganesa Masa Kadiri dan Singosari, Sebuah Tinjauan Sejarah Kesenian, Jakarta, LIPI.

[13] Soedarso, S.P. 2000. Trilogi Seni, Penciptaan Eksistensi dan Kegunaan Seni, 2006, 18-19. 
[14] Tolstoy, L.N. 1960. What is Art?, Bobb-Merrill, Indianapolis, New York, 25.

[15] Wiryomartono, A.B. 2001. Pijar-Pijar Penyingkap Rasa, Sebuah Wacana seni Keindahan dari Plato sampai Derrida, Jakarta, PT. Gramedia. 